\title{
Diatoms as an indicator for tile drainage flow in a German lowland catchment
}

\author{
Naicheng $\mathrm{Wu}^{1,2^{*}} \mathbb{0}$, Claas Faber $^{1}$, Uta Ulrich ${ }^{1}$ and Nicola Fohrer ${ }^{1}$
}

\begin{abstract}
Background: The separation of runoff components within a model simulation is of great importance for a successful implementation of management measures. Diatoms could be a promising indicator for tile drainage flow due to their diverse preferences to different aquatic habitats. In this study, we collected diatom samples of 9 sites (4 tile drainage, TD, and 5 river sites, Ri) in a German lowland catchment at a weekly or biweekly time step from March to July 2013 with the aim of testing the suitability of diatoms for tile drainage flow, which is typical for lowland catchment.

Results: Planothidium lanceolatum, Ulnaria biceps, and Navicula gregaria dominated in TD sites with relative abundances of 22.2, 21.5, and 10.9\%, respectively. For Ri sites, the most abundant species was Navicula lanceolata (20.5\%), followed by Ulnaria biceps (12.9\%), Cyclotella meneghiniana (9.5\%), and Planothidium lanceolatum (9.3\%). Compared with Ri sites, TD had a lower diatom density, biomass, species richness, and percentage of Aquatic/Riparian diatoms (AqRi\%). However, the proportion of Riparian diatoms (RiZo\%) increased at TD. Indicator value method (IndVal) revealed that the two groups (Ri and TD) were characterized by different indicator species. Fifteen taxa, including Cocconeis placentula, Cyclotella meneghiniana, N. lanceolata, and U. biceps, were significant indicators for Ri sites. Planothidium lanceolatum, Achnanthidium minutissimum, and Navicula gregaria were significant indicators for TD sites.

Conclusion: A pronounced variation was found in the species lists of diatom community between Ri and TD water body types associated with different indicator species. With respect to hydrograph separation, these findings highlight the suitability of diatoms as an indicator for tile drainage flow. However, spatial and temporal variations of diatoms should be considered in future surveys.
\end{abstract}

Keywords: Diatoms, Indicator value method, Runoff components, Tracer

\section{Background}

Lowland areas are characterized by low hydraulic gradients, shallow groundwater, flat topography, high potential for water retention, and a large amount of tile drainages in agricultural areas [1-4]. In such regions, drainage flow plays an important role and should be considered in modeling [5]. As a process-based ecohydrological river basin model, the SWAT model (Soil and Water Assessment Tool) [6] has already been used successfully in lowland catchments [1, 7-9]. However, the influence of drainage networks, groundwater dynamics, wetlands,

\footnotetext{
*Correspondence: nwu@hydrology.uni-kiel.de; naichengwu88@gmail. com

${ }^{2}$ Aarhus Institute of Advanced Studies, Aarhus University,

Høegh-Guldbergs Gade 6B, 8000 Aarhus C, Denmark

Full list of author information is available at the end of the article
}

and ponds on model performance was very pronounced [4]. Besides, tile drainages are difficult to incorporate into models using standard data sources and techniques due to the lack of information about the location and characteristics of the tile drainage system [1]. For a successful implementation of management measures, the separation of runoff components within a model simulation becomes of particular interest, when the transport pattern of contaminants (e.g., phosphorus, nitrogen, pesticide) is the target of a model application. In this regard, hydrologists are endeavoring to search reliable tracers that can identify and assess runoff-generating processes and detect sources of stream flow components within a target catchment [10-12]. Common tracers may be stable isotopes (Deuterium, oxygen-18, etc.) and radioactive isotopes (i.e., carbon-14). Biotic tracers, which may be 
applied for runoff process studies, are algae. Diatoms, for example, have been identified by $[13,14]$ as a potential tracer for surface runoff. Recent studies have investigated the relationships between stream diatoms with hydrological variables [15] as well as terrestrial and riparian diatoms and found that the origin of diatom species during floods partly stemmed from riparian and/or terrestrialupland habitats $[14,16]$. Nevertheless, the use of diatoms as a tracer in catchment hydrology is still very limited up to now [14].

Diatoms are unicellular, eukaryotic algae with high species diversity, which can be observed in nearly every aquatic environment including fresh and marine waters, moist terrestrial habitats, such as soils, rock surfaces, or epiphytes $[17,18]$. A distinct feature of diatoms is their highly differentiated cell wall (called frustule), which mainly consists of silica $\left(\mathrm{SiO}_{2}\right)$. Their frustules consist of two valves and show an enormous diversity in shape. These species-specific cell wall ornamentations enable the diagnosis of diatoms and form the basis of diatom taxonomy and systematic. Diatoms have been widely applied in marine ecosystem research [19-22] and have a high potential as tracers of particular matters or processes such as sources of suspended matter [23], coastal upwelling [24], and climate change [25]. In streams and rivers, diatoms are commonly used as reliable environmental indicators based on several merits, e.g., base of food webs and food chains [26], high sensitivity to physico-chemical and biological changes [27, 28], and cosmopolitan character with a wide geographical distribution and well-known autecology of most species $[29,30]$. The small cell with sizes varying commonly between 10 and $200 \mu \mathrm{m}$ in diameter or length [31] allows them to be easily transported by water. As a consequence, many assessment methods based on diatoms have been developed in several countries and regions [22, 32] for different environmental stressors such as flow regulation [33-35], nutrient enrichment [36], and heavy metal pollution [37].

Nevertheless, diatoms have so far not been introduced as general freshwater tracers of hydrological processes, especially in lowland areas. Based on the habitat preferences of distinct diatom species [29], a higher concentration of terrestrial diatoms is related to the occurrence of surface runoff during runoff events. Considering the potential usage of drift diatoms to link the terrestrial and aquatic worlds, Pfister et al. [13] proposed to use diatoms as a tracer of water resources and hydrological connectivity in the mountainous Attert catchment. The preliminary results of Martínez-Carreras et al. [38] showed that diatoms can help detect the onset/cessation of surface runoff. However, apart from the above-mentioned studies, investigations on diatoms as tracers are rarely found, and to our knowledge, except for $[13,14,16]$, there is no investigation using diatoms as a tracer of hydrological processes.

The objectives of this study are to (1) investigate diatom assemblages at tile drainage sites, (2) compare the diatoms between river and tile drainage sites, and (3) identify indicator species for tile drainage sites in a German lowland catchment. Our hypothesis is that the diatoms at tile drainage sites are different from river sites due to their particular habitats.

\section{Methods}

\section{Description of the study area}

The Kielstau catchment, an UNESCO demosite for Ecohydrological since 2010 [39], is a lowland watershed with a drainage area of $50 \mathrm{~km}^{2}$, and located in the Northern part of Germany (Schleswig-Holstein). It has its origin in the upper part of Lake Winderatt and is a tributary of the Treene River (Fig. 1) [27]. The precipitation is $841 \mathrm{~mm} / \mathrm{a}$ (station Satrup, 1961-1990) [40] and the mean annual temperature is $8.2{ }^{\circ} \mathrm{C}$ (station Flensburg, 1961-1990) [40]. Moorau (MR) and Hennebach (HB) are two main tributaries within the Kielstau catchment. The drained fraction of agricultural area in the Kielstau catchment is estimated to be $38 \%$ [41] and various small tributaries and water from drainage pipes and ditches discharge into the river Kielstau. Sandy, loamy, and peat soils are characteristic for the catchment. Land use is dominated by arable land and pasture $(\sim 55$ and $\sim 26 \%$, respectively, of the catchment area) $[4,41]$.

\section{Sampling methods and primary procedures}

At 4 tile drainage (TD) and 5 river sites (Ri), samples were taken weekly or biweekly from March to July 2013. A total of 40 tile drainage and 63 river samples were analyzed. At each site and on every sampling date, the volume of diatom samples was determined and samples were filtered through a $20-\mu \mathrm{m}$ plankton net. The retained organisms were transferred into $50-\mathrm{mL}$ glass bottles and fixed in 5\% non-acetic Lugol's iodine solution [42]. After $48 \mathrm{~h}$, the supernatant liquid of undisturbed samples is carefully removed and samples are thus concentrated to $30 \mathrm{~mL}$ for further processing.

Simultaneously, at each sampling point, water temperature (WT), $\mathrm{pH}$, electric conductivity (EC), and dissolved oxygen (DO) of the surface water were measured in situ using Portable Meter (WTM Multi 340i and WTW Cond 330i, Germany). Discharge $\left(\mathrm{m}^{3} / \mathrm{s}\right)$ was calculated by either beaker with timer (for TD sites with small discharge such as TD1, TD2, and TD3) or velocity-area method at the sampling points (for stream sites and TD4) (velocity-using FlowSens Single Axis Electromagnetic Flow Meter, Hydrometrie, Germany). Concurrently, water samples were taken in two pre-cleaned plastic 

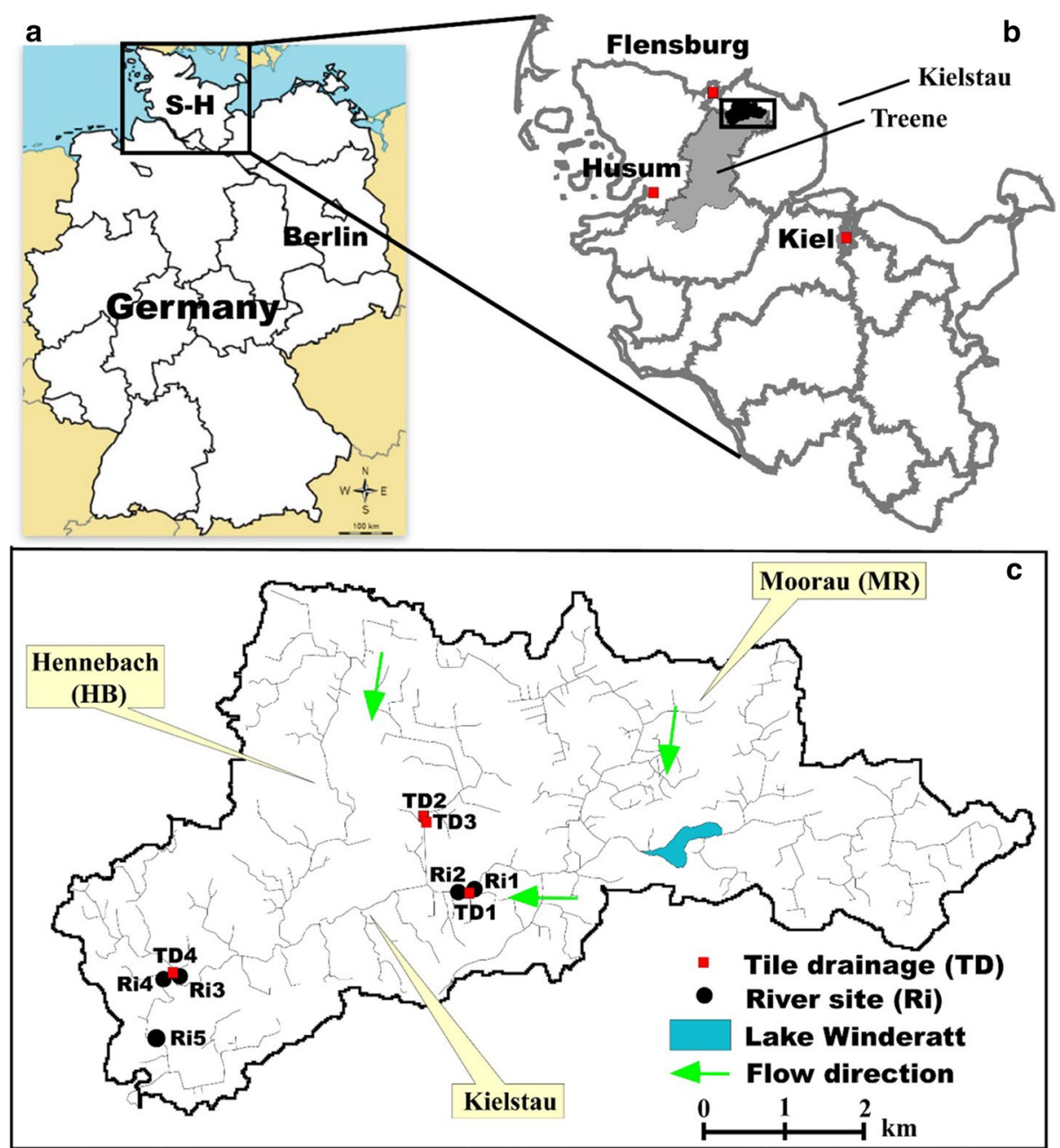

Fig. 1 The location of sampling sites in Kielstau catchment (c), Schleswig-Holstein state (b), Northern Germany (a). S-H = Schleswig-Holstein state

bottles (500 mL each) for water chemistry measurement in the laboratory. In the lab, water samples were partially filtrated through GF/F glass microfiber filter (Whatmann 1825-047) for measurements of phosphate-phosphorus $\left(\mathrm{PO}_{4}-\mathrm{P}\right)$, ammonium-nitrogen $\left(\mathrm{NH}_{4}-\mathrm{N}\right)$, nitrate-nitrogen $\left(\mathrm{NO}_{3}-\mathrm{N}\right)$, nitrite-nitrogen $\left(\mathrm{NO}_{2}-\mathrm{N}\right)$, chloride $\left(\mathrm{Cl}^{-}\right)$ and sulfate $\left(\mathrm{SO}_{4}^{2-}\right)$ according to the standard methods DEV (Deutsche Einheitsverfahren zur Wasser-, Abwasser- und Schlammuntersuchung). The concentrations of total phosphorus (TP) were measured with unfiltered water samples. $\mathrm{PO}_{4}-\mathrm{P}$ and $\mathrm{TP}$ were measured using the ammonium molybdate spectrophotometric method (at $880 \mathrm{~nm}$; DIN 1189). We used Nessler's reagent colorimetric method (DIN 38 406-E5-1) to measure $\mathrm{NH}_{4}-\mathrm{N}$ concentrations at $690 \mathrm{~nm} . \mathrm{NO}_{3}-\mathrm{N}, \mathrm{NO}_{2}-\mathrm{N}, \mathrm{Cl}^{-}$, and $\mathrm{SO}_{4}^{2-}$ were measured by an ion chromatography method (DIN 38 405-D19).

\section{Identification under microscope}

Permanent diatom slides were prepared after oxidizing the organic material by nitric acid and sulfuric acid and a minimum of 300 valves were counted for each sample using a Zeiss Axioskop microscope at $1000 \times$ under oil immersion. Diatoms were identified to the lowest taxonomic level possible (mainly species level) according to Simonsen [43], Round et al. [17], and Lange-Bertalot [44-47]. Their densities were expressed as cell/L. Diatom biomass was estimated by taxa biovolumes (by closest geometric form supposing specific gravity of $1.00 \mathrm{~g} / \mathrm{cm}^{3}$ ) $[48,49]$.

\section{Data analyses}

Besides total density and total diatom biomass, we calculated community diversity indices. They were BergerParker diversity [50], evenness [51], HillN1 diversity [52], 
Margalef's diversity [53], McNaughton diversity [54], Menhinick diversity [55], Shannon-Wiener diversity $\left(H^{\prime}\right)$ [56], Simpson's Dominance, and species richness to describe the diatom assemblage. Since the occurrence of diatom species is bound to specific habitat and wetness conditions, diatoms were classified into five moisture categories and then we calculated their relative abundances [29]: Aquatic zone (AqZo\%), Aquatic/Riparian transition zone (AqRi\%), Riparian zone (RiZo\%), Riparian/Upland transition zone (RiUp\%), and Upland zone (UpZo\%) (Table 1). The classification was also reorganized into two habitat categories, namely Aquatic\% and Terrestrial\%.
Mann-Whitney $U$ tests were used to compare their differences between Ri and TD sites.

The indicator value method (IndVal) was used to detect how strongly each species discriminated between $\mathrm{Ri}$ and TD groups. The indicator value of a taxon varied from 0 to 100 , and the indicator value attained its maximum value when all individuals of a taxon occurred at all sites within a single group. We tested the significance of the indicator value for each species with a Monte Carlo randomization procedure with 1000 permutations. We ran IndVal with PC-ORD (Version 4; MjM Software Design, Gleneden Beach, Oregon).

Table 1 Classification of the moisture indices

\begin{tabular}{llll}
\hline Category & Code & Diatom habitat & Diatom occurrence \\
\hline 1 & AqZo & Aquatic zone & Never, or only very rarely, occurring outside water bodies \\
2 & AqRi & Aquatic/Riparian transition zone & Mainly occurring in water bodies, sometimes on wet places \\
3 & RiZo & Riparian zone & Mainly occurring in water bodies, also rather regularly on wet and moist places \\
4 & RiUp & Riparian/Upland transition zone & Mainly occurring on wet and moist or temporarily dry places \\
5 & UpZo & Upland zone & Nearly exclusively occurring outside water bodies \\
\hline
\end{tabular}
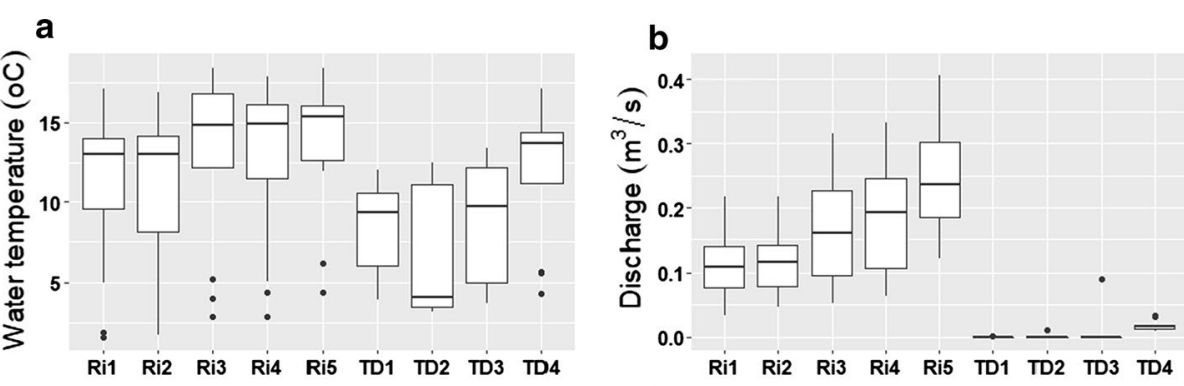

C

d

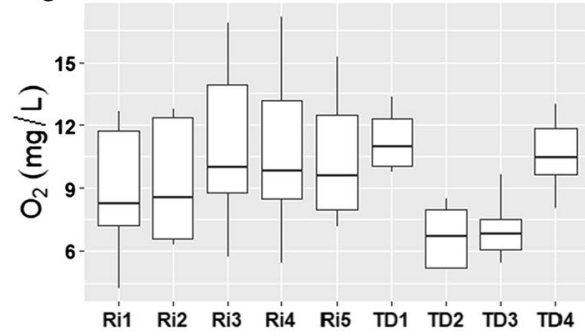

e

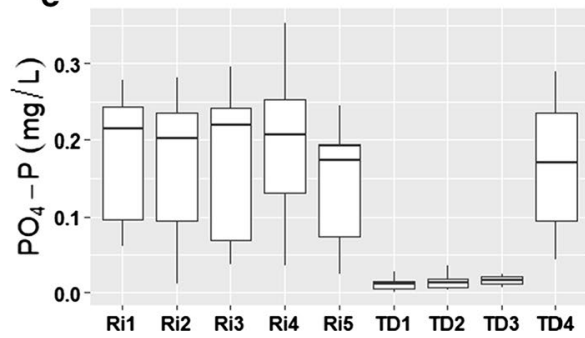

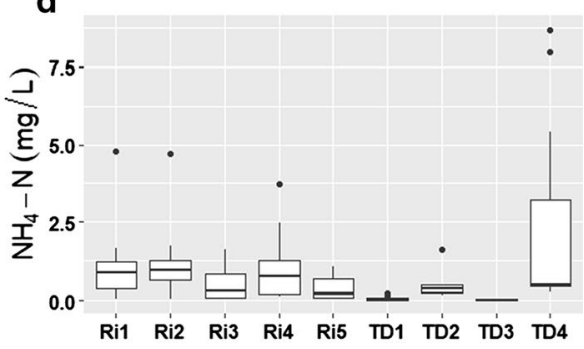

$f$

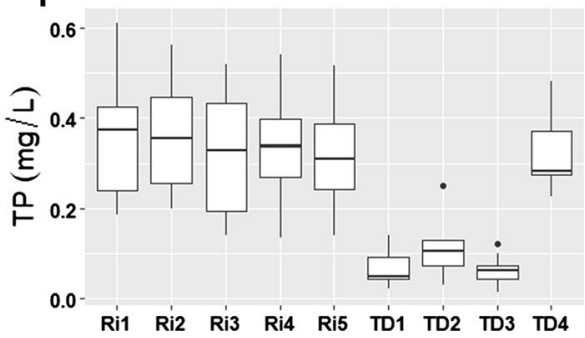

Fig. 2 Box plots of main environmental conditions including water temperature (a), discharge $(\mathbf{b}), \mathrm{O}_{2}(\mathbf{c}), \mathrm{NH}_{4}-\mathrm{N}(\mathbf{d}), \mathrm{PO} \mathrm{O}_{4} \mathrm{P}(\mathbf{e})$, and TP $(\mathbf{f})$ at different sampling sites. Boxes show interquartile ranges (25th and 75th\%), middle lines are medians, whiskers are non-outlier ranges beyond the boxes, and dots are outliers 


\section{Results}

Study reaches varied greatly in water-quality and habitat characteristics (Fig. 2). In comparison to river sites (Ri), sites of tile drainages (TD) demonstrated a lower average temperature (Fig. 2a), $\mathrm{O}_{2}$ contents (except for TD1 and TD4) (Fig. 2c), and smaller discharge (Fig. 2b). Nutrient concentrations (e.g., $\mathrm{NH}_{4}-\mathrm{N}, \mathrm{PO}_{4}-\mathrm{P}$, and TP) of TD1TD3 were dramatically lower than those of Ri sites and TD4 (Fig. 2d-f). For example, the mean discharges of TD1-TD4 were $0.21 \mathrm{~L} / \mathrm{s}, 1.97 \mathrm{~L} / \mathrm{s}, 9.04 \mathrm{~L} / \mathrm{s}$, and $18.05 \mathrm{~L} / \mathrm{s}$, respectively, while the discharges of $\mathrm{Ri} 1-\mathrm{Ri} 5$ averaged 85.39 L/s, $114.06 \mathrm{~L} / \mathrm{s}, 168.06 \mathrm{~L} / \mathrm{s}, 186.12 \mathrm{~L} / \mathrm{s}$, and 241.50 $\mathrm{L} / \mathrm{s}$, respectively. The TP concentrations of TD1-TD3 were $0.067 \mathrm{mg} / \mathrm{L}, 0.119 \mathrm{mg} / \mathrm{L}$, and $0.062 \mathrm{mg} / \mathrm{L}$, respectively. In contrast, TP concentrations of Ri1-Ri5 and TD4 were $0.365 \mathrm{mg} / \mathrm{L}, 0.368 \mathrm{mg} / \mathrm{L}, 0.325 \mathrm{mg} / \mathrm{L}, 0.326 \mathrm{mg} / \mathrm{L}$, $0.311 \mathrm{mg} / \mathrm{L}$, and $0.315 \mathrm{mg} / \mathrm{L}$, respectively.

A total of 78 diatom species were recorded in this study. Within all samples, Navicula lanceolata (Ehrenberg), Ulnaria biceps (Kützing), and Planothidium lanceolatum (Brébisson ex Kützing) were the most abundant species, whose relative abundances were 17.7, 14.4, and $11.5 \%$ of the total abundance, respectively. Planothidium lanceolatum, Ulnaria biceps, and Navicula gregaria (Donkin) dominated in tile drainage (TD) sites with relative abundances of $22.2,21.5$, and $10.9 \%$, respectively. For river (Ri) sites, the most abundant species was Navicula lanceolata (20.5\%), followed by Ulnaria biceps (12.9\%), Cyclotella meneghiniana (Kützing) (9.5\%), and Planothidium lanceolatum (9.3\%). In general, TD had lower diatom density, biomass, species richness, HillN1 diversity, and percentage of Aquatic/Riparian diatoms (AqRi\%) than those of Ri (Table 2). However, the proportion of Riparian diatoms (RiZo\%) increased at TD (Table 2).

Both diversity and moisture indices are in the same range at Ri sites (Ri1-Ri5) (Figs. 3, 4). Nevertheless, TD sites varied and TD4 exhibited a particular case. Similar with Ri sites, TD4 had higher diatom density, biomass, species richness than those of TD1-TD3 (Fig. 3). Whereas, moisture indices of TD4 (e.g., AqRi\% and RiZo\%) were quite similar with TD1-TD3 (Fig. 4). Temporal variations of different diatom indices are shown at Figs. 5, 6. Ri sites demonstrated clear temporal variations. For example, AqRi\% decreased while RiZo\% increased from March 28 to June 27, 2013. However, TD sites changed very randomly without a significant temporal trend as of Ri sites (Figs. 5, 6).

Table 2 The comparisons of diatom indices between river (Ri) and tile drainage (TD) sites

\begin{tabular}{|c|c|c|c|c|c|c|c|c|}
\hline \multirow[t]{2}{*}{ Diatom indices } & \multicolumn{4}{|c|}{$\operatorname{Ri}(n=63)$} & \multicolumn{4}{|c|}{$\mathrm{TD}(\mathrm{n}=40)$} \\
\hline & Min & $\operatorname{Max}$ & Mean & SD & Min & Max & Mean & SD \\
\hline Density (cells/L)** & 33,480 & 750,804 & 202,544 & 113,400 & 156 & 565,041 & 67,643 & 121,417 \\
\hline Biomass $(\mathrm{mg} / \mathrm{L})^{* *}$ & 0.09 & 2.53 & 0.52 & 0.37 & 0.00 & 1.93 & 0.19 & 0.37 \\
\hline \multicolumn{9}{|l|}{ Diversity indices } \\
\hline Margalef's** & 0.79 & 2.21 & 1.26 & 0.24 & 0.00 & 1.47 & 0.82 & 0.40 \\
\hline Evenness & 0.47 & 0.88 & 0.78 & 0.08 & 0.44 & 1.00 & 0.81 & 0.15 \\
\hline Richness** & 14.00 & 35.00 & 22.89 & 4.00 & 1.00 & 25.00 & 13.03 & 6.68 \\
\hline Shannon-Wiener** & 1.56 & 2.87 & 2.42 & 0.29 & 0.00 & 2.73 & 1.84 & 0.65 \\
\hline Simpson's** & 0.08 & 0.47 & 0.15 & 0.07 & 0.09 & 1.00 & 0.26 & 0.21 \\
\hline Berger-Parker* & $\underline{0.14}$ & $\underline{0.68}$ & $\underline{0.29}$ & $\underline{0.12}$ & $\underline{0.17}$ & $\underline{1.00}$ & $\underline{0.38}$ & $\underline{0.20}$ \\
\hline McNaughton ${ }^{* *}$ & 0.27 & 0.72 & 0.42 & 0.11 & 0.30 & 1.00 & 0.56 & 0.20 \\
\hline Odum ${ }^{* *}$ & 0.03 & 0.81 & 0.16 & 0.14 & 0.03 & 12.26 & 1.96 & 2.51 \\
\hline Menhinick** & 0.03 & 0.17 & 0.06 & 0.02 & 0.02 & 0.37 & 0.11 & 0.07 \\
\hline HillN1** & 4.76 & 17.61 & 11.70 & 3.10 & 1.00 & 15.31 & 7.38 & 3.64 \\
\hline \multicolumn{9}{|l|}{ Moisture indices } \\
\hline AqZo\% & 3.70 & 38.24 & 17.29 & 7.51 & 0.00 & 76.67 & 19.60 & 18.03 \\
\hline $\mathrm{AqRi} \% * *$ & 25.00 & 80.08 & 53.58 & 14.68 & 0.00 & 75.00 & 23.84 & 17.74 \\
\hline RiZo\%** & 7.85 & 63.33 & 28.13 & 12.16 & 0.00 & 100.00 & 52.26 & 23.61 \\
\hline RiUp\% & 0.00 & 4.21 & 1.00 & 1.05 & 0.00 & 100.00 & 4.30 & 16.01 \\
\hline UpZo\% & 0.00 & 0.00 & 0.00 & 0.00 & 0.00 & 0.00 & 0.00 & 0.00 \\
\hline Aquatic\% & 95.79 & 100.00 & 99.00 & 1.05 & 0.00 & 100.00 & 95.70 & 16.01 \\
\hline Terrestrial\% & 0.00 & 4.21 & 1.00 & 1.05 & 0.00 & 100.00 & 4.30 & 16.01 \\
\hline
\end{tabular}

AqZo Aquatic zone, AqRi Aquatic/Riparian transition zone, RiZo Riparian zone, RiUp Riparian/Upland transition zone, UpZo Upland zone $p>0.05 ;{ }^{*} \underline{p} \leq \underline{0.05} ;{ }^{* *} p<0.001$ (Mann-Whitney U tests) 


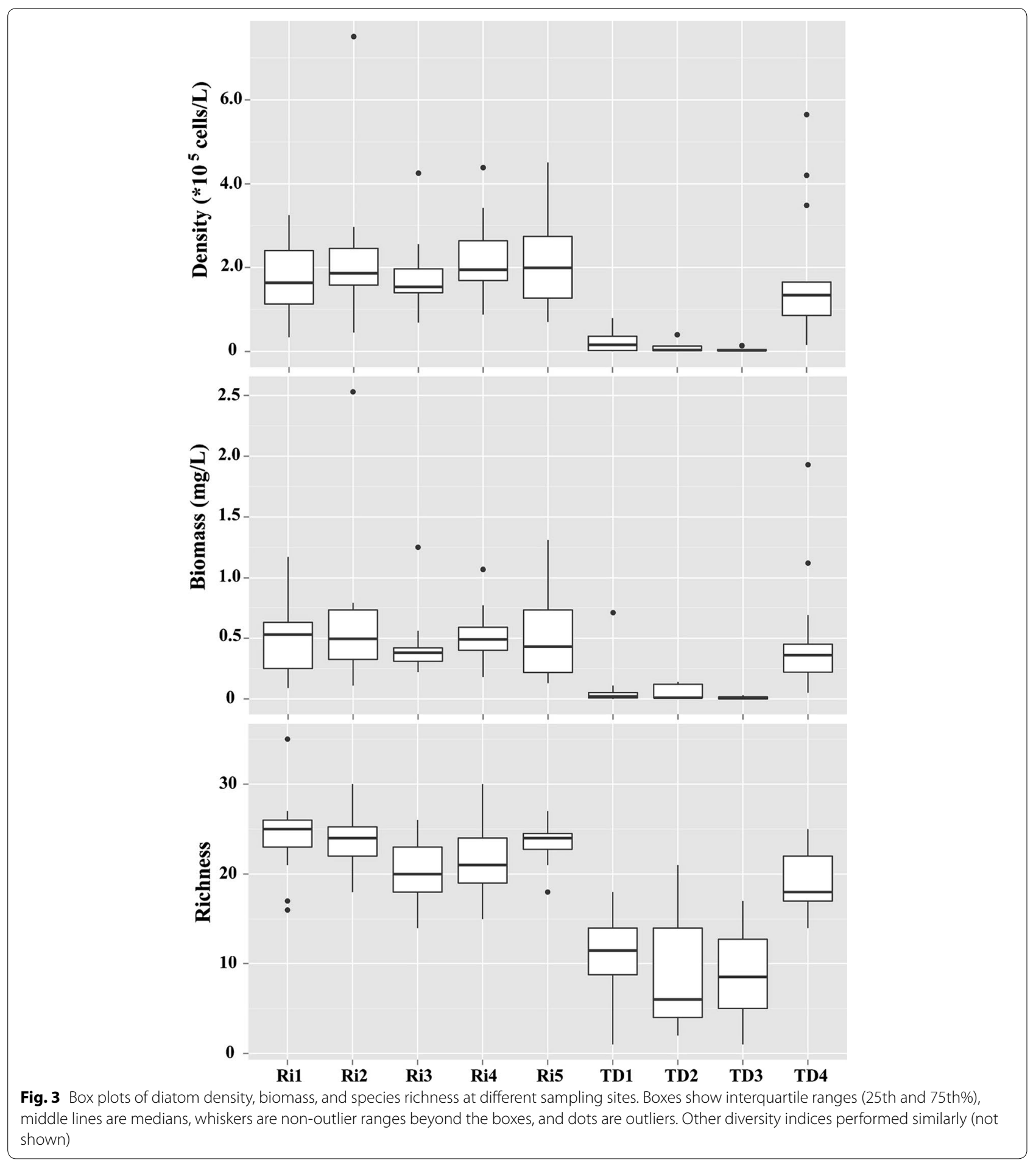

To identify the key indicator species of the river and tile drainage groups, the indicator value method (IndVal) was used and showed that the two groups were characterized by different indicator species (Table 3). Fifteen taxa, including Cocconeis placentula (Ehrenberg), Cyclotella meneghiniana, Navicula lanceolata, and Ulnaria biceps, were significant indicators for Ri sites. Planothidium lanceolatum, Achnanthidium minutissimum (Kützing), and Navicula gregaria, with small cell sizes, were significant indicators for TD sites. 


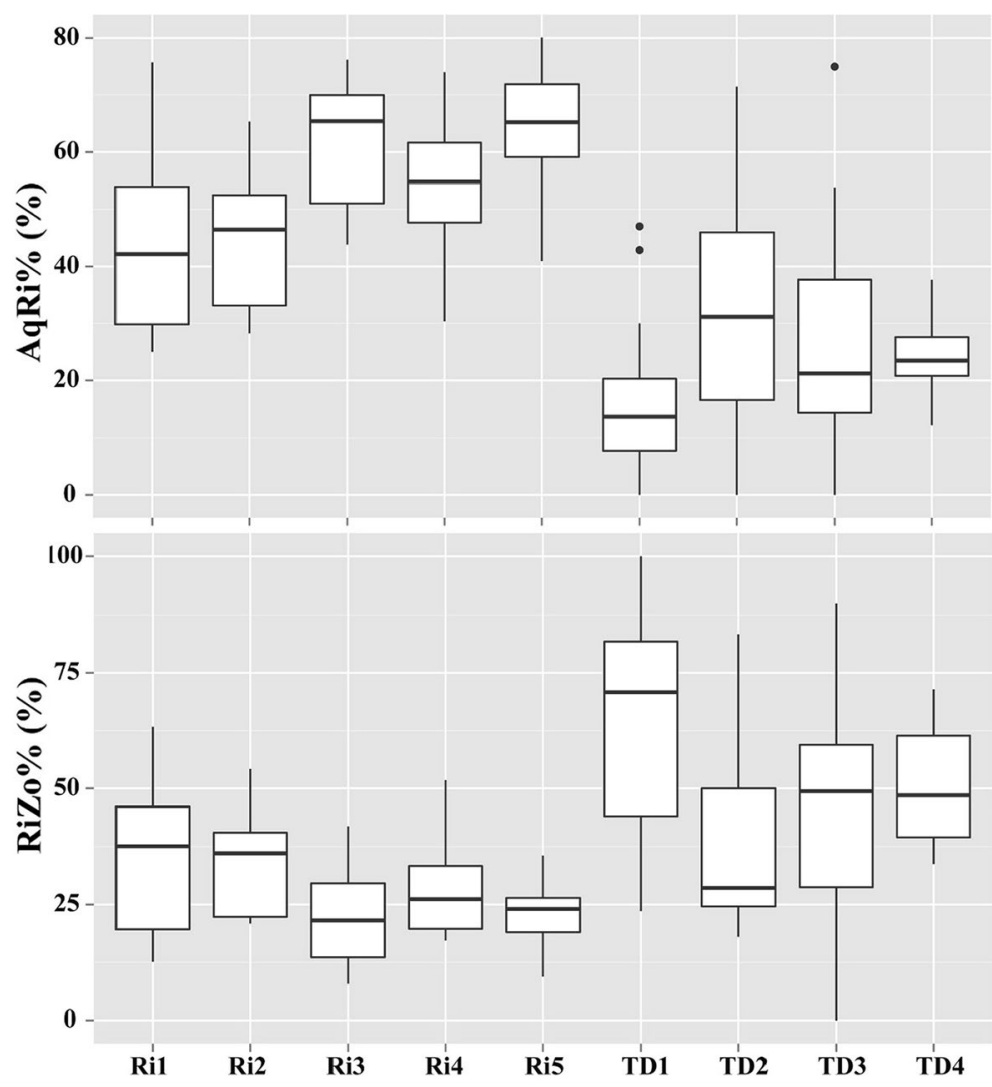

Fig. 4 Box plots of AqRi\% and RiZo\% at different sampling sites. Boxes show interquartile ranges (25th and 75th\%), middle lines are medians, whiskers are non-outlier ranges beyond the boxes, and dots are outliers. AqRi, Aquatic/Riparian transition zone; RiZo, Riparian zone

\section{Discussion}

The analyses revealed a high variation in diatom community between tile drainage (TD) and river (Ri) sites in the study area with considerable different species composition and many species showed pronounced affinities with one water body type. For example, some species, like Cocconeis placentula, Eunotia bilunaris (Ehrenberg), Fragilaria elliptica (Schumann), Melosira granulata (Ehrenberg), Synedra binodis (Ehrenberg), and Tabellaria flocculosa (Kützing), were clearly associated with Ri sites. In contrast, Navicula gregaria, Reimeria sinuata (Kociolek \& Stoermer) were mainly found in TD systems. Cocconeis placentula is relatively resistant to scour and prefers high current habitat because of the prostrate growth form and firm attachment via mucus secreted by the raphe valve. Reimeria sinuata with small cell size $(8-20 \mu \mathrm{m})$ occurs mainly in water bodies, also rather regularly on wet and moist places [29]. Furthermore, compared with Ri sites, TD had much lower diatom density, biomass, and species richness (density: $0.68 \times 10^{5}$ vs. $2.03 \times 10^{5}$ cells/L, biomass: 0.19 vs. $0.52 \mathrm{mg} / \mathrm{L}$, species richness: 13 vs. 23 ).

An important reason for these differences is probably the specific habitat character of tile drainage. Since the water flows through a subsurface drainage pipe, light is almost not available at TD sites. This significantly reduces the possibility of photosynthesis that absorbs sunlight to synthesize carbohydrates from $\mathrm{CO}_{2}$ and water. Therefore, theoretically diatoms should not exist at TD sites, but actually we did observe many diatom species. One hypothesis was that the detected diatoms at TD sites were transported through soil macropores during runoff events [57]. Our results supported this hypothesis since the dominant species of TD sites were either of small sizes (e.g., Planothidium lanceolatum, Achnanthidium minutissimum, and Navicula gregaria) or long filamentous cells (e.g., Ulnaria biceps). These characters allow them to be transported easily by flowing water. Nevertheless, on the other hand, if this hypothesis was right, the diatom species of TD sites should be categorized as terrestrial species (i.e., RiUp or UpZo) because they origin from the moist top soil. This was not the case in this survey since most diatoms of TD were AqRi and RiZo species (Figs. 5, 6). It is still not clear, how surface runoff and tile drainage flow interact with regard to runoff generation, dynamics of nutrient, and contaminant losses [58]. Further investigations are thus needed to clarify 


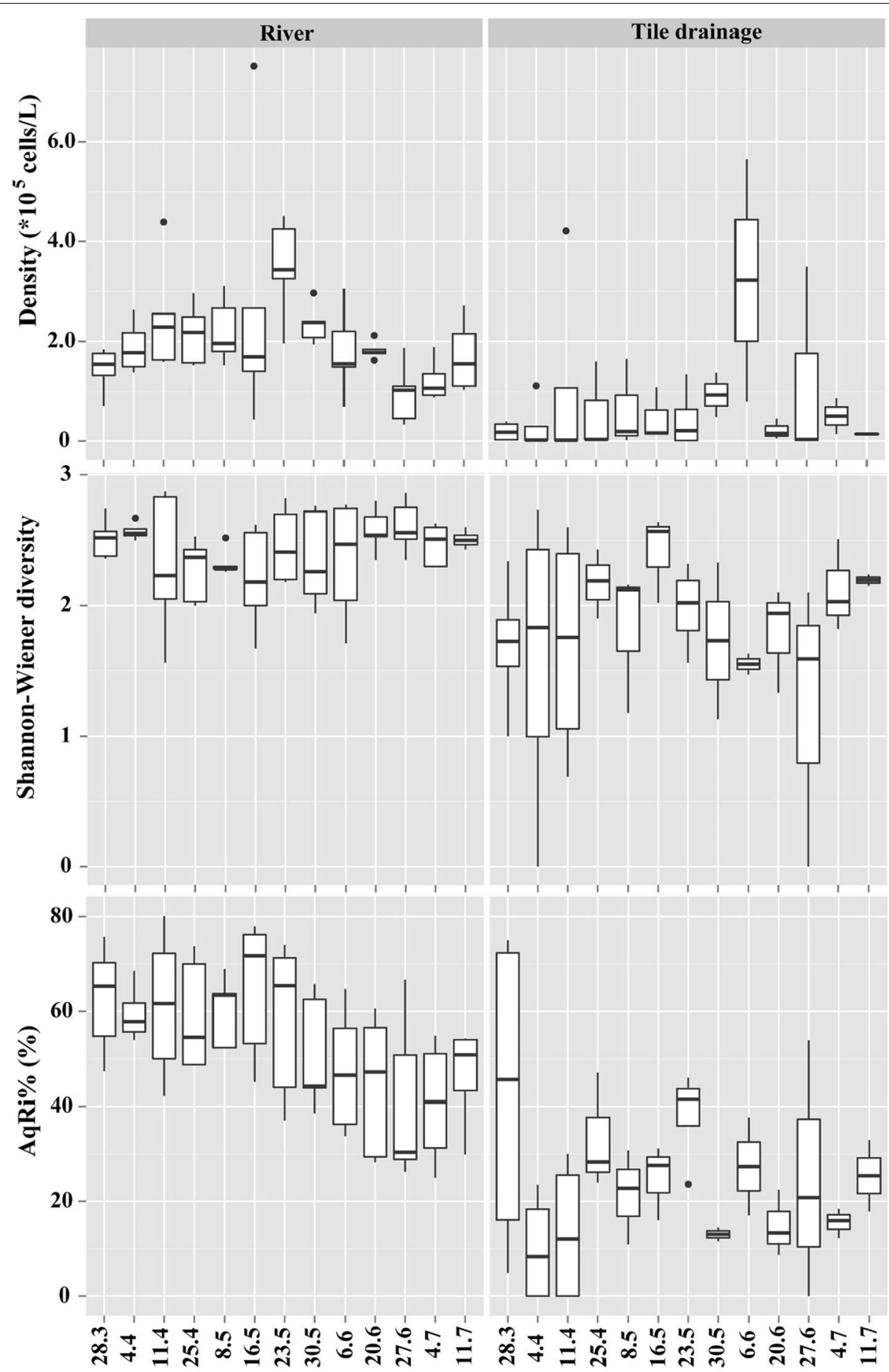

Fig. 5 Temporal variations of different diatom indices at river (Ri) and tile drainage (TD) sites. Boxes show interquartile ranges (25th and 75th percentiles), middle lines are medians, whiskers are non-outlier ranges beyond the boxes, and dots are outliers. Other diversity indices performed similarly (not shown) 


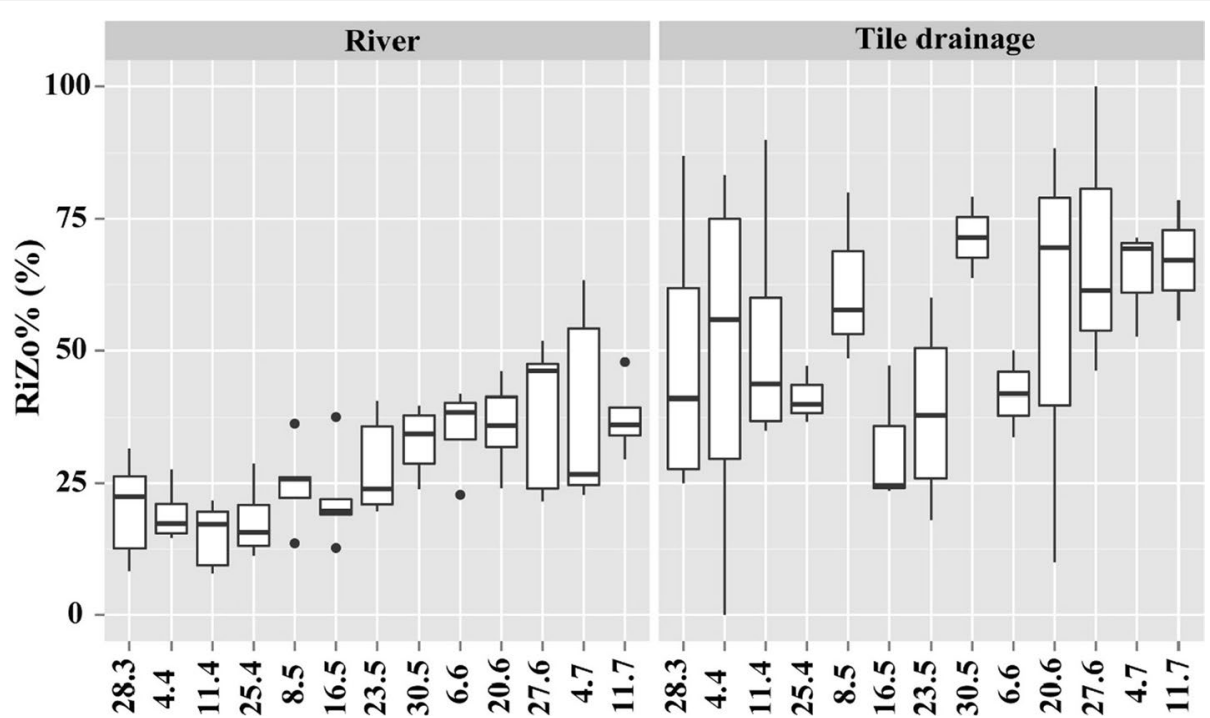

Fig. 6 Temporal variations of RiZo\% at river (Ri) and tile drainage (TD) sites. Boxes show interquartile ranges (25th and 75th percentiles), middle lines are medians, whiskers are non-outlier ranges beyond the boxes, and dots are outliers. Other diversity indices performed similarly (not shown)

Table 3 Summary of indicator species analysis showing indicator taxa, relative abundance, relative frequency, and indicator value (IV) for each group

\begin{tabular}{|c|c|c|c|c|c|c|}
\hline \multirow[t]{2}{*}{ Species } & \multicolumn{2}{|c|}{ Relative abundance } & \multicolumn{2}{|c|}{ Relative frequency } & \multicolumn{2}{|l|}{ IV } \\
\hline & $\mathrm{Ri}$ & TD & $\mathrm{Ri}$ & TD & $\mathbf{R i}$ & TD \\
\hline Amphora ovalis (Kützing) & 95 & 5 & 27 & 3 & 26 & 0 \\
\hline Cocconeis placentula (Ehrenberg) & 82 & 18 & 90 & 25 & 74 & 5 \\
\hline Cyclotella meneghiniana (Kützing) & 74 & 26 & 92 & 55 & 68 & 15 \\
\hline Fragilaria biceps (Kützing) & 61 & 39 & 100 & 60 & 61 & 24 \\
\hline Fragilaria elliptica (Schumann) & 75 & 25 & 59 & 10 & 44 & 2 \\
\hline \multirow[t]{2}{*}{ Fragilaria leptostauron (Ehrenberg) } & 100 & 0 & 14 & 0 & 14 & 0 \\
\hline & 87 & 13 & 16 & 3 & 14 & 0 \\
\hline Meridion circulare (Greville) & 61 & 39 & 83 & 48 & 50 & 19 \\
\hline Navicula lanceolata (Ehrenberg) & 73 & 27 & 97 & 80 & 71 & 22 \\
\hline Navicula perrotettii (Grunow) & 86 & 14 & 25 & 5 & 22 & 1 \\
\hline Navicula viridula (Kützing) & 62 & 38 & 86 & 45 & 53 & 17 \\
\hline Nitzschia sigma (Kützing) & 58 & 42 & 90 & 43 & 52 & 18 \\
\hline Staurosira phoenicenteron (Ehrenberg) & 100 & 0 & 22 & 0 & 22 & 0 \\
\hline Surirella elegans (Ehrenberg) & 63 & 37 & 68 & 25 & 43 & 9 \\
\hline Synedra binodis (Ehrenberg) & 100 & 0 & 27 & 0 & 27 & 0 \\
\hline Planothidium lanceolatum (Brébisson ex Kützing) & 32 & 68 & 100 & 90 & 32 & 61 \\
\hline Achnanthidium minutissimum (Kützing) & 20 & 80 & 83 & 78 & 16 & 62 \\
\hline Navicula gregaria (Donkin) & 33 & 67 & 92 & 85 & 30 & 57 \\
\hline
\end{tabular}

Ri river sites, $T D$ tile drainage sites

The italic numbers are significant indicator values $(p<0.05$, Monte Carlo permutation test)

the source or transfer processes of the observed diatom species.

Regardless of the origins of TD diatoms, there may be several reasons why Ri sites are richer in species than
TD sites: (1) in comparison with TD, rivers are more heterogeneous in space and are less susceptible to drying out. This allows a potentially higher number of species to successfully settle in these systems; (2) the degree 
of connectivity may also play an important role. Rivers tend to have larger catchment areas than tile drainage system and have therefore a higher chance of being colonized from neighboring water bodies; (3) local stress events (e.g., inflow of pesticides or nutrients) have a larger impact on small water bodies than on larger-sized systems.

A second finding of this study was that TD4 performed differently compared to the other $3 \mathrm{TD}$ sites. This result is generally attributed to its catchment area and nutrient supply. TD4 has a larger catchment area than those of TD1-TD3, which could be judged by their discharges (Fig. 2). For example, on 28th March, the discharge of TD4 was $17 \mathrm{~L} / \mathrm{s}$ contributing $9.05 \%$ of downstream river discharge, whereas the contribution of TD1 to downstream river was only $0.069 \%$ with a discharge of $0.071 \mathrm{~L} / \mathrm{s}$. Tile drainages with larger catchments have a greater physical habitat complexity. Therefore there is a higher possibility of gathering other sources of diatoms and being colonized from neighboring water bodies. Furthermore, there was a wastewater treatment plant discharging into TD4, which provided major nutrient inputs (i.e., nitrogen and phosphorus) for diatom growth. This implied that spatial variations of tile drainages were remarkable and should be noted in further investigations, especially with respect to hydrograph separation.

Temporal variations were observed at $\mathrm{Ri}$ sites, which was in accordance with a former study in the Kielstau catchment [59]. The importance of seasonality to many organisms in aquatic systems, including diatoms, is not yet well known. Microbiological fluxes are usually highest in summer as higher temperature causes higher biological activity and reproduction, particularly in humid environments when moisture is not a limiting factor [60]. However, in this study we did not detect significant temporal variations at TD sites (Figs. 5, 6). One explanation is the habitat character of tile drainage, as mentioned above, is relatively stable compared with river water and less influenced by short-term climate changes (e.g., temperature, sunshine, and wind changes). Furthermore, the groundwater influence in the tile drainages keeps the water temperature constantly cool. Moreover, the use of the plankton net with a mesh size of $20 \mu \mathrm{m}$ inevitably results in the loss of species smaller than $20 \mu \mathrm{m}$ (or in filament) and may have important consequences for the present results. Besides, the time span of this study is very short and tile drainage fell dry in summer when high temperatures could have an impact. Although we have found significant temporal variations of Ri sites, it should be noted that this study is based on a short-term sampling campaign during a low-flow period. The situation during floods may change and dramatically influence the results. It has particular significance when we aim to select tracers, which should be temporally constant or their variations should be known [61]. Thus, further studies will consist in assessing the temporal variations of diatom community for reducing uncertainties in hydrological process identification and quantification. In addition, a rain-event-based sampling campaign in a discharge dependent sampling mode is being conducted. These data could be used to detect hydrological processes and diatom community.

\section{Conclusion}

We found a pronounced variation in the species lists of diatom community between Ri and TD water body types. Indicator value method (IndVal) revealed that 15 taxa and 3 taxa were significant indicators for Ri and TD sites, respectively. With respect to hydrograph separation, these findings highlight the suitability of diatoms as an indicator of tile drainage flow contribution. However, the source or transport pathways of the observed TD species need to be clarified. Spatial and temporal variations should be considered in a future survey.

\section{Authors' contributions}

NW, CF, UU, and NF developed the basic ideas. NW and CF collected the samples and did the lab analyses. NW calculated the diatom indices, performed the data analyses, and led the main writing. All authors have seen the manuscript before submission. All authors read and approved the final manuscript.

\section{Author details}

${ }^{1}$ Department of Hydrology and Water Resources Management, Institute for Natural Resource Conservation, Kiel University, Kiel, Germany. ${ }^{2}$ Aarhus Institute of Advanced Studies, Aarhus University, Høegh-Guldbergs Gade 6B, 8000 Aarhus C, Denmark.

\section{Acknowledgements}

We thank Mrs. Monika Westphal, Mrs. Bettina Hollmann, and other colleagues for their supports during the field campaigns. Dr. Georg Hörmann provided help on R manipulation. The constructive comments of three anonymous reviewers greatly improved our manuscript.

\section{Competing interests}

The authors declare that they have no competing interests.

Availability of data and materials

Not applicable.

Consent for publication

Not applicable.

Ethics approval and consent to participate

Not applicable.

Funding

This study was supported financially by an AIAS-Cofund grant and DFG Grants (FO 301/15-1, FO 301/15-2, WU 749/1-1, WU 749/1-2).

\section{Publisher's Note}

Springer Nature remains neutral with regard to jurisdictional claims in published maps and institutional affiliations.

Received: 8 December 2017 Accepted: 15 January 2018

Published online: 15 February 2018 


\section{References}

1. Kiesel J, Fohrer N, Schmalz B, White MJ (2010) Incorporating landscape depressions and tile drainages of a northern German lowland catchment into a semi-distributed model. Hydrol Process 24(11):1472-1486

2. Schmalz B, Fohrer N (2009) Comparing model sensitivities of different landscapes using the ecohydrological SWAT model. Adv Geosci 7:1-7

3. Schmalz B, Fohrer N (2010) Ecohydrological research in the German lowland catchment Kielstau. IAHS Publ 336:115-120

4. Schmalz B, Tavares F, Fohrer N (2008) Modelling hydrological processes in mesoscale lowland river basins with SWAT - capabilities and challenges. Hydrol Sci J 53(5):989-1000

5. Yuan Y, Mitchell JK, Hirschi MC, Cooke RAC (2001) Modified SCS curve number method for predicting subsurface drainage flow. Anglais 44(6):1673-1682

6. Arnold JG, Srinivasan R, Muttiah RS, Williams JR (1998) Large area hydrologic modelling and assessment Part I. Model development. JAWRA. J Am Water Resour Assoc 34(1):73-89

7. Guse B, Kail J, Radinger J, Schröder M, Kiesel J, Hering D, Wolter C, Fohrer N (2015) Eco-hydrologic model cascades: simulating land use and climate change impacts on hydrology, hydraulics and habitats for fish and macroinvertebrates. Sci Total Environ 533:542-556

8. Kiesel J, Guse B, Pfannerstill M, Kakouei K, Jähnig SC, Fohrer N (2017) Improving hydrological model optimization for riverine species. Ecol Ind 80:376-385

9. Lam QD, Schmalz B, Fohrer N (2011) The impact of agricultural best management practices on water quality in a North German lowland catchment. Environ Monit Assess 183:351-379

10. Goller R, Wilcke W, Leng MJ, Tobschall HJ, Wagner K, Valarezo C, Zech W (2005) Tracing water paths through small catchments under a tropical montane rain forest in south Ecuador by an oxygen isotope approach. $J$ Hydrol 308(1-4):67-80

11. Hoeg S, Uhlenbrook S, Leibundgut C (2000) Hydrograph separation in a mountainous catchment-combining hydrochemical and isotopic tracers. Hydrol Process 14(7):1199-1216

12. Peters N, Ratcliffe E (1998) Tracing hydrologic pathways using chloride at the Panola Mountain Research Watershed, Georgia, USA. Water Air Soil Pollut 105(1):263-275

13. Pfister L, McDonnell JJ, Wrede S, Hlúbiková D, Matgen P, Fenicia F, Ector $L$, Hoffmann $L$ (2009) The rivers are alive: on the potential for diatoms as a tracer of water source and hydrological connectivity. Hydrol Process 23(19):2841-2845

14. Pfister L, Wetzel CE, Klaus J, Martínez-Carreras N, Antonelli M, Teuling AJ, McDonnell JJ (2017) Terrestrial diatoms as tracers in catchment hydrology: a review. Wiley Interdiscip Rev. https://doi.org/10.1002/wat2.1241

15. Wu N, Faber C, Sun X, Qu Y, Wang C, Ivetic S, Riis T, Ulrich U, Fohrer N (2016) Importance of sampling frequency when collecting diatoms. Sci Rep 6:36950

16. Pfister L, Wetzel CE, Martínez-Carreras N, Frentress J, Ector L, Hoffmann L, McDonnell J (2011) Do diatoms run downhill? Using biodiversity of terrestrial and aquatic diatoms to identify hydrological connectivity between aquatic zones in Luxembourg. In: AGU Fall Meeting

17. Round FE, Crawford RM, Mann DG (1990) The diatoms: biology and morphology of the genera. Cambridge University Press, Cambridge

18. Hoffmann L (1989) Algae of terrestrial habitats. Bot Rev 55(2):77-105

19. Abrantes F, Lopes C, Mix A, Pisias N (2007) Diatoms in southeast Pacific surface sediments reflect environmental properties. Quatern Sci Rev 26(1-2):155-169

20. Armbrust EV (2009) The life of diatoms in the world's oceans. Nature 459(7244):185-192

21. Spielmeyer A, Pohnert G (2012) Influence of temperature and elevated carbon dioxide on the production of dimethylsulfoniopropionate and glycine betaine by marine phytoplankton. Mar Environ Res 73:62-69

22. Wu N, Dong X, Liu Y, Wang C, Baattrup-Pedersen A, Riis T (2017) Using river microalgae as indicators for freshwater biomonitoring: review of published research and future directions. Ecol Ind 81:124-131

23. Huault MF, Lafite R, Dupont JP (1994) Diatoms as particulate tracers in the water column in the eastern english channel. Neth J Sea Res 33(1):47-56

24. Bao R, Varela M, Prego R (1997) Mesoscale distribution patterns of diatoms in surface sediments as tracers of coastal upwelling of the Galician Shelf (NW Iberian Peninsula). Mar Geol 144(1-3):117-130
25. Gasse F, Barker P, Gell PA, Fritz SC, Chalie F (1997) Diatom-inferred salinity in palaeolakes: an indirect tracer of climate change. Quatern Sci Rev 16(6):547-563

26. Hötzel G, Croome R (1999) A phytoplankton methods manual for australian freshwaters. LWRRDC occasional Paper 22/99

27. Qu Y, Wu N, Guse B, Fohrer N (2018) Riverine phytoplankton shifting along a lentic-lotic continuum under hydrological, physiochemical conditions and species dispersal. Sci Tot Environ. https://doi.org/10.1016/j. scitotenv.2017.10.139

28. Wang C, Li X, Wang X, Wu N, Yang W, Lai Z, Lek S (2016) Spatio-temporal patterns and predictions of phytoplankton assemblages in a subtropical river delta system. Fund Appl Limnol 187(4):335-349

29. van Dam H, Mertens A, Sinkeldam J (1994) A coded checklist and ecological indicator values of freshwater diatoms from the Netherlands. Neth J Aquat Ecol 28:117-133

30. Porter S (2008) Algal attributes: an autecological classification of algal taxa collected by the National Water-Quality Assessment Program. In U.S. Geological Survey Data Series 329, http://pubs.usgs.gov/ds/ds329/. Accessed Jan 2016

31. Mann DG (2002) Diatoms: organism and image. In: du Buf H, Bayer MM (eds) Automatic diatom identification. World Scientific Publishing, Singapore, pp 9-40

32. Siddig AAH, Ellison AM, Ochs A, Villar-Leeman C, Lau MK (2016) How do ecologists select and use indicator species to monitor ecological change? Insights from 14 years of publication in ecological indicators. Ecol Ind 60:223-230

33. Wu NC, Cai QH, Fohrer N (2012) Development and evaluation of a diatom-based index of biotic integrity (D-IBI) for rivers impacted by runof-river dams. Ecol Ind 18:108-117

34. Wu NC, Jiang WX, Fu XC, Zhou SC, Li FQ, Cai QH, Fohrer N (2010) Temporal impacts of a small hydropower plant on benthic algal community. Fundam Appl Limnol Archiv Hydrobiol 177(4):257-266

35. Wu NC, Tang T, Fu XC, Jiang WX, Li FQ, Zhou SC, Cai QH, Fohrer N (2010) Impacts of cascade run-of-river dams on benthic diatoms in the Xiangxi River, China. Aquat Sci 72(1):117-125

36. Wu NC, Schmalz B, Fohrer N (2012) Development and testing of a phytoplankton index of biotic integrity (P-IBI) for a German lowland river. Ecol Ind 13(1):158-167

37. Dong XY, Jia XH, Jiang WX, Wu NC, Tang T, Cai QH (2015) Development and testing of a diatom-based index of biotic integrity for river ecosystems impacted by acid mine drainage in Gaolan River, China. Fresen Environ Bull 24:4114-4124

38. Martínez-Carreras N, Frentress J, Iffly, JF, McDonnell J, Hlúbiková D, Ector L, Uhlenbrook S, Hoffmann L, Pfister L (2011) Using diatoms for determining the hydrological connectivity between upland, riparian and aquatic zones: application to the Weierbach catchment (Luxembourg). Geophys Res Abstr 13

39. Fohrer N, Schmalz B (2012) The UNESCO ecohydrology demosite Kielstau catchment: sustainable water resources management and education in rural areas. Hydrol und Wasserwirtschaft 56:160-168

40. DWD (2010) Mean values of the precipitation and temperature for the period 1961-1990. www.dwd.de. Access 18 Jun 2010

41. Fohrer N, Schmalz B, Tavares F, Golon J (2007) Ansätze zur Integration von landwirtschaftlichen Drainagen in die Modellierung des Landschaftswasserhaushalts von mesoskaligen Tieflandeinzugsgebieten. Hydrol Wasserbewirtschaftung 51(4):164-169

42. Sabater S, Artigas J, Duran C, Pardos M, Romani A, Tornes E, Ylla I (2008) Longitudinal development of chlorophyll and phytoplankton assemblages in a regulated large river (the Ebro River). Sci Tot Environ 404(1):196-206

43. Simonsen R (1987) Atlas and catalogue of the diatom types of Friedrich Hustedt, vol 1-3. Schweizerbart Science Publishers, Berlin

44. Lange-Bertalot H (2000a) Iconographia Diatomologica. Annotated Diatom Micrographs, vol 7. Scientific Books, Koenigstein, Germany

45. Lange-Bertalot H (2000b) Iconographia Diatomologica. Annotated Diatom Micrographs, vol 9. Scientific Books, Koenigstein, Germany

46. Lange-Bertalot H (2005) Iconographia Diatomologica. Annotated Diatom Micrographs, vol 15. Scientific Books, Koenigstein, Germany

47. Lange-Bertalot H (2007) Iconographia Diatomologica. Annotated Diatom Micrographs, vol 18. Scientific Books, Koenigstein, Germany 
48. Hillebrand H, Dürselen C, Kirschtel D, Pollingher U, Zohary T (1999) Biovolume calculation for pelagic and benthic microalgae. J Phycol 35:403-424

49. Padisák J, Adrian R (1999) Biologische Gewässeruntersuchung,Chapter 5. 1. In: Tümpling VW, Friedrich G (eds) In Methoden der Biologischen Wasseruntersuchung 2. Gustav Fischer Verlag, Jena, pp 334-367

50. Berger W, Parker F (1970) Diversity of planktonic foraminifera in deep sediments. Science 168:1345-1347

51. Pielou $E$ (1966) The measurement of diversity in different types of biological collections. J Theor Biol 13:131-144

52. Spatharis S, Tsirtsis G (2010) Ecological quality scales based on phytoplankton for the implementation of Water Framework Directive in the eastern Mediterranean. Ecol Ind 10(4):840-847

53. Margalef R (1958) Information theory in ecology. Gen Syst 3:36-71

54. McNaughton J (1967) Relationship among functional properties of California grassland. Nature 216:168-169

55. Menhinick E (1964) A comparison of some species-individuals diversity indices applied to samples of field insects. Ecology 45:859-861
56. Shannon C, Weaver W (1949) The mathematical theory of communication. University of Illinois Press, Urbana

57. Tauro F, Martínez-Carreras N, Barnich F, Juilleret J, Wetzel CE, Ector L, Hissler C, Pfister L (2016) Diatom percolation through soils: a proof of concept laboratory experiment. Ecohydrology 9:753-764

58. Gentry LE, David MB, Royer TV, Mitchell CA, Starks KM (2007) Phosphorus transport pathways to streams in tile-drained agricultural watersheds. J Environ Qual 36(2):408-415

59. Wu NC, Schmalz B, Fohrer N (2011) Distribution of phytoplankton in a German lowland river in relation to environmental factors. J Plankton Res 33(5):807-820

60. Rodgers P, Soulsby C, Hunter C, Petry J (2003) Spatial and temporal bacterial quality of a lowland agricultural stream in northeast Scotland. Sci Tot Environ 314(Supplement C):289-302

61. Leibundgut C, Piotr M, Christoph K (2009) Tracers in hydrology. Wiley, Hoboken

\section{Submit your manuscript to a SpringerOpen ${ }^{\circ}$ journal and benefit from:}

- Convenient online submission

- Rigorous peer review

- Open access: articles freely available online

- High visibility within the field

- Retaining the copyright to your article

Submit your next manuscript at $\boldsymbol{\nabla}$ springeropen.com 